\title{
Cataract-congenital heart disease-neural tube defect syndrome
}

INSERM

\section{Source}

INSERM. (1999). Orphanet: an online rare disease and orphan drug data base. Cataractcongenital heart disease-neural tube defect syndrome. ORPHA:314993

Cataract-congenital heart disease-neural tube defect syndrome is a multiple congenital anomaly syndrome characterized by sacral neural tube defects resulting in tethered cord, atrial and/or ventricular septal heart defects (that are detected in infancy), bilateral, symmetrical hyperopia, rapidly prog ressive early childhood cataracts, bilateral aphakic glaucoma, and abnormal facial features (low frontal hairline, small ears, short philtrum, prominent, widely spaced central incisors, and microg nathia). Hypotonia, growth and developmental delay, seizures, and joint limitation are also reported. 